PETIR: Jurnal Pengkajian dan Penerapan Teknik Informatika Vol. 13, No. 1, Maret 2020, P-ISSN 1978-9262, E-ISSN 2655-5018 DOI: https://doi.org/10.33322/petir.v13i1.768

\title{
Implementasi Algoritma Neural Network untuk Mendukung Keputusan di Desa Tamanmekar
}

\author{
Amril mutoi siregar ${ }^{1}$; Hanny Hikmayanti $H^{2}$ \\ ${ }^{1,2}$ Fakultas Teknologi dan Ilmu Komputer, Universitas Buana Perjuangan Karawang \\ ${ }^{1}$ Amrilmutoi@ubpkarawang.ac.id \\ 2hanny.hikmayanti@ubpkarawang.ac.id
}

\begin{abstract}
The welfare level of rural communities, mainly those which far from urban area, are still widely found under the poverty line. Given the root of the problem is that almost all villages do not have the correct, accurate and precise data about the condition of the problem and the potential of the village owned. In fact, the central government channeled the budget for each village, almost reaching 1 billion annually. By not having accurate and correct data, the development of improper targets including the channeling of poor people's Rice (Raskin), and Direct Cash Assistance (BLT). There are still misdirected target, unsuitable with the program planned by the government. This research is expected to be one of the solutions to analyze population data, both for problems intact and the potential aspects the village has, so that the channeling of the aid can be on target. The data processing methodis used so that the village can have true and accurate data. The selection of features in this study is using the Neural Network algorithm, the accuracy of the research algorithm is $94.96 \%$. Thus, it can be used as a reference for data processing for government assistance programs.
\end{abstract}

Keywords: data mining, decision, neural network, artificial network

\begin{abstract}
ABSTRAK
Tingkat kesejahteraan masyarakat pedesaan yang terutama jauh dari perkotaan, masih banyak ditemukan dibawah garis kemiskinan. Mengingat akar permasalahannya adalah hampir semua desa tidak mempunyai data yang benar, akurat dan tepat tentang kondisi permasalahan dan potensi desa yang dimiliki. Padahal pemerintah pusat menyalurkan anggaran tiap tahun untuk setiap desa, hampir mencapai 1 milyar pertahun. Dengan tidak memiliki data yang akurat dan benar, sehingga pembangunan tidak tepat sasaran termasuk penyaluran beras rakyat miskin (Raskin), Bantuan langsung tunai $(B L T)$. Masih ditemukan penyaluran yang tidak tepat sasaran, sesuai dengan yang direncanakan oleh pemerintah. Dengan penelitian ini diharapkan salah cara untuk menganalisa data penduduk, baik permasalahan dan potensi yang dimiliki. Sehingga penyaluran bantuan lainya tepat sasaran. Metode pengolahan data, untuk diimplementasikan agar desa memiliki data yang benar dan akurat. Untuk seleksi fitur dalam penelitian ini menggunakan algoritma Neural Network (Jaringan syaraf tiruan), hasil accuracy algoritma penelitian ini adalah $94.96 \%$. Sehingga dapat digunakan sebagai referensi untuk mengolah data untuk Bantuan dari pemerintah.
\end{abstract}

Kata kunci: Datamining, keputusan, Neural Network, Jaringan saraf tiruan 
PETIR: Jurnal Pengkajian dan Penerapan Teknik Informatika

Vol. 13, No. 1, Maret 2020, P-ISSN 1978-9262, E-ISSN 2655-5018

DOI: https://doi.org/10.33322/petir.v13i1.768

\section{PENDAHULUAN}

\subsection{Latarbelakang}

Dengan adanya kemajuan teknologi informasi semakin pesat dalam berbagai bidang. Seiring perkembangannya tentu mendukung pula adanya suatu sistem informasi yang dapat mengolah data secara cepat, tepat, akurat, dan tentu saja bermanfaat sesuai dengan kebutuhan terutama untuk mengambil keputusan. Pada saat ini sistem informasi pendataan penduduk di Desa Tamanmekar kecamatan Pangkalan Kabupaten Karawang Propinsi Jawa barat, masih bersifat pembukuan atau secara manual. Cara sistem pembukuan tersebut akan sulit dalam proses pendataan penduduk yang jumlahnya sangat banyak. Seperti jumlah penduduk yang actual dan laporan penghitungan jumlah penduduk perbulan akan terasa sulit. Karena adanya penduduk yang lahir, penduduk mati, penduduk datang dan penduduk pindah. Dengan permasalahan ketidak konsistensian data, pencarian data yang membutuhkan waktu yang sangat lama dan kemungkinan kehilangan data sehingga potensi desa yang dimiliki tidak dapat di kelola dengan baik.

Ketika data sudah lengkap dengan dukungan teknologi informasi dan ada yang lebih penting yaitu menganalisa potensi yang dimiliki desa guna dalam pengambilan keputusan tepat sasaran, misalnya penyaluran anggaran untuk kesejahteraan desa dan bantuan bantuan lain misalnya fasilitas Raskin dan Bantuan Langsung tunai, Jamkesmas dan lain lain. Keputusan adalah suatu tindakan yang dilakukan para pimpinan/manajer untuk menentukan suatu kesimpulan tentang apa yang harus dilakukan atau tidak dilakukan dalam situasi tertentu. Keputusan ini dinyatakan dalam suatu bentuk kata-kata yang dirumuskan dalam suatu peraturan, perintah, intruksi, kebijakan dan dalam bentuk apa saja yang dikehendaki pimpinan. Dalam proses penyelesaian masalah dalam pembuatan keputusan, yaitu tindakan memilih diantara berbagai alternative solusi untuk pemecahan masalah.

Untuk mendukung keputusan yang akan dilakukan oleh manajeman dibutuhkan informasi yang berguna dengan tipe informasi yang berbeda untuk setiap tingkatan manajemen. Manajemen tingkat bawah, tipe informasinya lebih inci dan detail karena informasi tersebut digunakan untuk pengendalian operasi, sedangkan untuk manajemen yang lebih tinggi tingkatannya, tipe informasinya semakin tersaring atau lebih ringkas. Langkah-Langkah Pengambilan Keputusan Menurut [9] pengambilan keputusan ini menyangkut 4 langkah pokok, yaitu: Menentukan diagnosa dari masalah yang sebenarnya, Rencanakan alternatif-alternatif yang ada, Memproyeksikan frekuensi dari pada berbagai alternatif setelah masalahnya diadakan diagnosa dan ditentukan adanya beberapa alternatif pemecahan yang telah diketahui, Membuat pilihan.

Ciri-ciri keputusan yang dapat di ukur sebagai rule memiliki empat konsep yaitu ciri-ciri keputusan dalam: Proses keputusan, Konsep ikatan, Penilaian (evaluation), Perilaku dengan maksud dan tujuan tertentu. Tipe keputusan menjadi 3 bagian yakni: Keputusan kelompok atau organisasi, yaitu dimana seseorang mempunyai peranan sebagai anggota dari kelompok itu sendiri, keputusan ini adalah keputusan resmi dari kelompok atau organisasi dan pemimpin yang bertindak sebagai pejabat pelaksana, Keputusan pribadi, yaitu keputusan yang di pertanggungjawabkan kepada setiap individu sekalipun sebagai anggota dari organisasi, Keputusan dasar, yaitu keputusan organisasi yang sangat penting dan di anggap sebagai bentuk khusus dari pada keputusan pokok.

Menurut [1] metode untuk mengklasifikasikan keputusan ada dua sisi, yaitu keputusan terprogram (programmed decision) bersifat repetitif dan rutin dalam hal prosedur tertentu digunakan untuk menanganinya sehingga keputusan tersebut tidak perlu dianggap baru setiap kali terjadi. Keputusan yang tidak terprogram (nonprogrammed decision) bersifat baru, tidak terstukur, dan penuh konsekuensi. Tidak terdapat metode yang pasti untuk menangani masalah seperti ini karena masalah tersebut belum pernah muncul sebelumnya, atau karena sifat dan stukturnya sulit dijelaskan dan kompleks. Pemilihan solusi yang terbaik dapat dipercaya dengan berbagai cara. Menurut [2] 
PETIR: Jurnal Pengkajian dan Penerapan Teknik Informatika Vol. 13, No. 1, Maret 2020, P-ISSN 1978-9262, E-ISSN 2655-5018 DOI: https://doi.org/10.33322/petir.v13i1.768

teori manajemen telah mengidentifikasi 3 pendekatan dalam memilih solusi, yaitu: Analisis, evaluasi atas pilihan-pilihan secara sistimatis, dengan mempertimbangkan konsekuensi pilihan-pilihan pada tujuan organisasi, Penilaian: proses pemikiran yang dilakukan oleh seorang manajer, Penawaran: negosiasi antara beberapa manajer.

\subsection{Penelitian terkait}

Terdapat beberapa penelitian terdahulu yang serupa dimana meneliti dengan menggunakan klasifikasi data mining metode decision tree dan naive bayes. Penelitian [3] Pemetaan Kecelakaan Lalu Lintas Berbasis Klasifikasi Naive Bayes dengan Parameter Infrastruktur Jalan”. Hasil dari penelitian tersebut yaitu prediksi dengan Naive Bayes menunjukan bahwa tingkat akurasi rata-rata berkisar antara $29.3653 \%$ sampai dengan $78.0415 \%$, ini menunjukan bahwa tidak semua infrastruktur jalan bisa digunakan sebagai parameter sebuah kecelakaan terjadi karena masih ada hasil prediksi yang berada di bawah 50\%[9].

Penelitian [4] "Analisis Kualitas Data dan Klasifikasi Data Pasien Kanker" Hasil dari penelitian ini yaitu telah menyelesaikan masalah missing value data pasien kanker dengan replace missing value. Decision Tree menghasilkan performa yang sedikit lebih baik dari Naive Bayes dalam menentukan klasifikasi. Metode Decision tree menghasilkan nilai akurasi sebesar $99.9988 \%$ sedangkan metode Naive Bayes menghasilkan akurasi sebesar $99.9799 \%$. Berdasarkan uji coba yang telah dilakukan, diperoleh bahwa Decision Tree memberikan hasil akurasi sedikit lebih baik dari Naive Bayes dengan selisih akurasi 0,0189\%. Namun demikian, secara umum metode Decision Tree dan Naive Bayes sama-sama memiliki akurasi yang baik dalam melakukan klasifikasi kemiripan data pasien.

\subsection{Data Mining}

Data mining berhubungan dengan bidang ilmu lainnya misalnya artificial intelligence, Database System, Statistic, Information Retrieval, Machine Learning, dan Komputasi dan lain-lain. Selain itu, data mining di support dalam beberapa bidang contoh NN (neural network), algoritma $K$ Means, Decision tree, algoritma C.4.5, KNN Algorithm, SVM, dan Nä̈ve Bayes algorithm dan sebagainya. Pengolahan gambar dengan menggunakan Pola, bagian data analysis, proses sinyal, dan beberapa survei tentang pemodelan dan metode yang dapat diambil kesimpulan, bahwa data mining diperlukan sebagai penunjuk, yang mana data mining menampilkan hasil atas sejarahnya, ditafsirkan untuk petunjuk mengenai dalam proses model data mining[9].

\section{METODE/PERANCANGAN PENELITIAN}

\subsection{Metode Penelitian}

Metode penelitian adalah langkah-langkah yang akan digunakan dalam penelitian ini, agar terstruktur dengan baik, sistematika ini menyebabkan proses penelitian dapat dipahami dan diikuti oleh pihak lain. Berikut metode penelitian yang digunakan. 


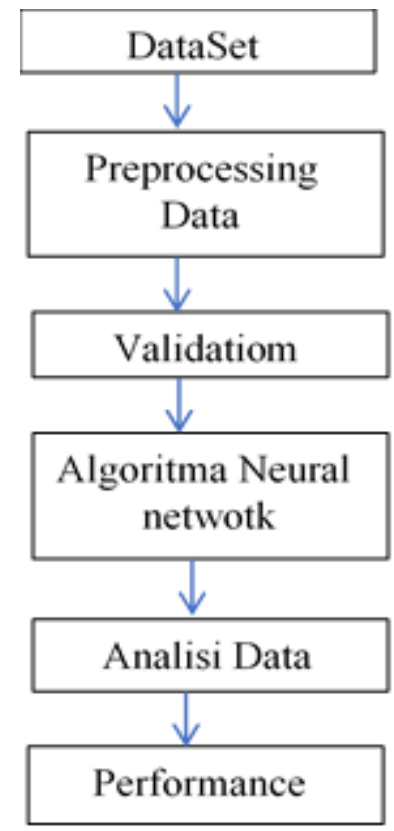

Gambar 1. Metode yang digunakan

Keterangan dari tahapan penelitian adalah:

\section{Dataset}

Data set yang gunakan adalah database warga Desa Tamanmekar Kec Pangkalan Kab Karawang. Atribut atau variabel yang digunakan dalam penelitian ini adalah sebagai berikut: NIK, Jumlah KK, Nama KK, Tempat, Tanggal Lahir, RT, JK, Status Dalam Keluarga, Pendidikan, Pekerjaan, Raskin, BPJS, Rmh Milik Sendiri, Dinding, Lantai, Atap, Toilet/WC, Air Minum, BLT.

\section{Preprocessing}

Preprocessing adalah proses setelah didapatkan dataset mentah dari situs pemerintah. Akan diproses sesuai dengan kebutuhan pada penelitian ini.

\section{Validation}

Validasi dalam penelitian ini adalah memastikan data yang digunakan sudah valid dan kesesuaian atribut yang digunakan untuk mengambil informasi yang dibutuhkan seperti transformasi data sehingga akan didapatkan data yang sudah dikurangi tingkat komplektisitasnya yang kemudian akan memudahkan proses pengolahan karena ukuran data yang diproses sudah menjadi lebih kecil.

\section{Algoritma neural network}

Setelah itu dilanjutkan untuk pengolahan data dimana yang pertama melakukan pengolahan dengan neural network, data akan diolah secara otomatis dengan bantuan software Rapid Miner. Neural Network dapat digunakan dalam berbagai tujuan, terutama classification dan predictive pada data mining. Neural Network awalnya dibangun dalam machine learning untuk mencoba meniru neurofisiologi dari otak manusia melalui kombinasi elemen komputasi sederhana (neuron) dalam sistem yang saling berhubungan. 
PETIR: Jurnal Pengkajian dan Penerapan Teknik Informatika Vol. 13, No. 1, Maret 2020, P-ISSN 1978-9262, E-ISSN 2655-5018 DOI: https://doi.org/10.33322/petir.v13i1.768

Menurut [5] cara kerja dari NNS dan otak manusia pada prinsipnya dikondensasikan dalam dua aspek berikut:

1. Pengetahuan diperoleh jaringan melalui proses pelatihan atau pembelajaran.

2. Intensitas koneksi antar neuron dikenal sebagai (synaptic) bobot yang digunakan untuk menyimpan pengetahuan yang diperoleh.

Salah satu kelebihan neural network adalah cukup baik dalam menangani data yang mengandung noise [6]. MLP terdiri dari input layer, satu atau lebih hidden layer, dan output layer. Berikut penjelasan masing-masing layer.

\section{a. Input layer}

Input layer untuk menerima nilai masukan dari tiap record pada data. Jumlah simpul input sama dengan jumlah variabel prediktor.

\section{b. Hidden layer}

Hidden layer mentransformasikan nilai input di dalam network. Jumlah hidden layer bisa berapa saja. Tiap simpul pada hidden layer terhubung dengan simpul-simpul pada hidden layer sebelumnya atau dari simpul-simpul pada input layer dan ke simpulsimpul pada hidden layer berikutnya atau ke simpul-simpul pada output layer.

\section{c. Output layer}

Garis yang terhubung dengan Output layer berasal dari hidden layer atau input layer dan mengembalikan nilai keluaran yang bersesuaian dengan variabel prediksi. Keluaran dari output layer biasanya merupakan nilai floating antara 0 sampai 1 . Penemuan algoritma back propagation untuk multilayer perceptron, merupakan metode yang sistematis untuk training sehingga bisa dilakukan dan lebih efisien. Algoritma back propagation berasal dari learning rule. Langkah pembelajaran dalam algoritma back propagation adalah sebagai berikut [7].

d. Inisialisasi bobot jaringan secara acak (biasanya antara -0.1 sampai 1.0)

Hitung input untuk simpul berdasarkan nilai input dan bobot jaringan saat itu untuk setiap data pada data training, menggunakan rumus:

$$
\text { Input }_{j}=\sum_{i=1}^{n}(O i W i j+\theta j)
$$

Keterangan:

$O_{i} \quad=$ Output simpul i dari layer sebelumnya

$W_{i j} \quad=$ bobot relasi dari simpul $\mathrm{i}$ pada layer sebelumnya ke simpul $\mathrm{j}$

$\theta_{j} \quad=$ bias (sebagai pembatas)

Berdasarkan input dari langkah dua, selanjutnya membangkitkan output untuk simpul menggunakan fungsi aktifasi sigmoid:

$$
\text { Output }=\frac{1}{\left(1+e^{- \text {input }}\right)}
$$

Hitung nilai Error antara nilai yang diprediksi dengan nilai yang sesungguhnya menggunakan rumus: 
Error $_{j}=$ Output $_{j} \cdot\left(1-\right.$ Output $\left._{j}\right) \cdot\left(\right.$ Target $_{j}-$ Output $\left._{j}\right)$

Keterangan:

Output $j=$ Output aktual dari simpul j

Target $j=$ Nilai target yang sudah diketahui pada data training

Setelah nilai Error dihitung, selanjutnya dibalik ke layer sebelumnya (back propagated). Untuk menghitung nilai Error pada hidden layer, menggunakan rumus:

Error $_{j}=$ Output $_{j}\left(1-\right.$ Output $\left._{j}\right) \sum_{k=1}^{n}($ Errork. Wjk $)$

Keterangan:

Output $_{j}=$ Output aktual dari simpul j

Error $_{k}=$ error simpul k

$W_{j k} \quad=$ Bobot relasi dari simpul $\mathrm{j}$ ke simpul $\mathrm{k}$ pada layer berikutnya

Nilai Error yang dihasilkan dari langkah sebelumnya digunakan untuk memperbarui bobot relasi menggunakan rumus

$W_{i j}=W_{i j}+$ 1. $_{\text {Erorr }_{j}}$. Output $_{i}$

Keterangan:

$W_{i j}=$ bobot relasi dari unit i pada layer sebelumnya ke unit $\mathrm{j}$

$l=$ learning rate (konstanta, nilainya antara 0 sampai dengan 1$)$

Error $_{j}=$ Error pada output layer simpul $\mathrm{j}$

Output ${ }_{I}=$ Output dari simpul i

\section{Analisa data}

Analisa data adalah melihat hasil yang didapat apa saja yang dapat diambil sebuah informasi yang berharga. Dan permasalah yang ditemui pada saat penelitian ini.

\section{Performance}

Hasil/performance adalah hasul dari pengolahan data yang sudah dilakukan akan ditentukan rule yang terbentuk untuk memberikan suatu keputusan dari algoritma.

\section{Confusion matrix}

Pengukuran terhadap kinerja suatu sistem klasifikasi merupakan hal yang penting. Kinerja sistem klasifikasi menggambarkan seberapa baik sistem dalam mengklasifikasikan data. Confusion matrix merupakan salah satu metode yang dapat digunakan untuk mengukur kinerja suatu metode klasifikasi. Pada dasarnya confusion matrix mengandung informasi yang membandingkan hasil klasifikasi yang dilakukan oleh sistem dengan hasil klasifikasi yang seharusnya. Pada jenis klasifikasi binary yang hanya memiliki 2 keluaran kelas, confusion matrix dapat disajikan seperti pada Tabel 1.

Tabel 1. Jenis Klasifikasi Binary

\begin{tabular}{|l|l|l|}
\hline Kelas & Terklasifikasi Positif & Terklasifikasi Negatif \\
\hline Positif & TP $($ True Positive $)$ & FN (False Negative $)$ \\
\hline Negatif & FP (False Positive $)$ & TN $($ True Negative $)$ \\
\hline
\end{tabular}


PETIR: Jurnal Pengkajian dan Penerapan Teknik Informatika Vol. 13, No. 1, Maret 2020, P-ISSN 1978-9262, E-ISSN 2655-5018

Berdasarkan nilai True Negative (TN), False Positive (FP), False Negative (FN), dan True Positive (TP) dapat diperoleh nilai akurasi, presisi dan recall. Nilai akurasi menggambarkan seberapa akurat sistem dapat mengklasifikasikan data secara benar. Dengan kata lain, nilai akurasi merupakan perbandingan antara data yang terklasifikasi benar dengan keseluruhan data. Nilai akurasi dapat diperoleh dengan Persamaan 1. Nilai presisi menggambarkan jumlah data kategori positif yang diklasifikasikan secara benar dibagi dengan total data yang diklasifikasi positif. Presisi dapat diperoleh dengan Persamaan 2. Sementara itu, recall menunjukkan berapa persen data kategori positif yang terklasifikasikan dengan benar oleh sistem. Nilai recall diperoleh dengan Persamaan 3.

dimana:

- TP adalah True Positive, yaitu jumlah data positif yang terklasifikasi dengan benar oleh sistem.

- TN adalah True Negative, yaitu jumlah data negatif yang terklasifikasi dengan benar oleh sistem.

- FN adalah False Negative, yaitu jumlah data negatif namun terklasifikasi salah oleh sistem.

- FP adalah False Positive, yaitu jumlah data positif namun terklasifikasi salah oleh sistem

\section{HASIL DAN PEMBAHASAN}

Penelitian ini menggunakan tools Rapidminer studio 9.2 untuk menganalisa data Klasifikasi yang diambil dari data Desa Tamanmekar, hasil yang ditampilkan dalam penelitian berupa Confusion matrix untuk akurasi dan grafik. Data yang digunakan pada penelitian ini adalah sebannyak $278 \mathrm{KK}$ terdiri dari 11 Atribut. Setelah dilakukan klasifikasi hasilnya akan dibandingan dengan persyaratan penerima BLT, sesuai dengan undang undang yang berlaku. Data training yang telah memiliki label diuji dengan Rapidminer dengan menggunakan jaringan syaraf tiruan (Deep Learning). Hasil penelitian ini seperti dibawah ini:

Tabel 2. Contoh dataset yang digunakan

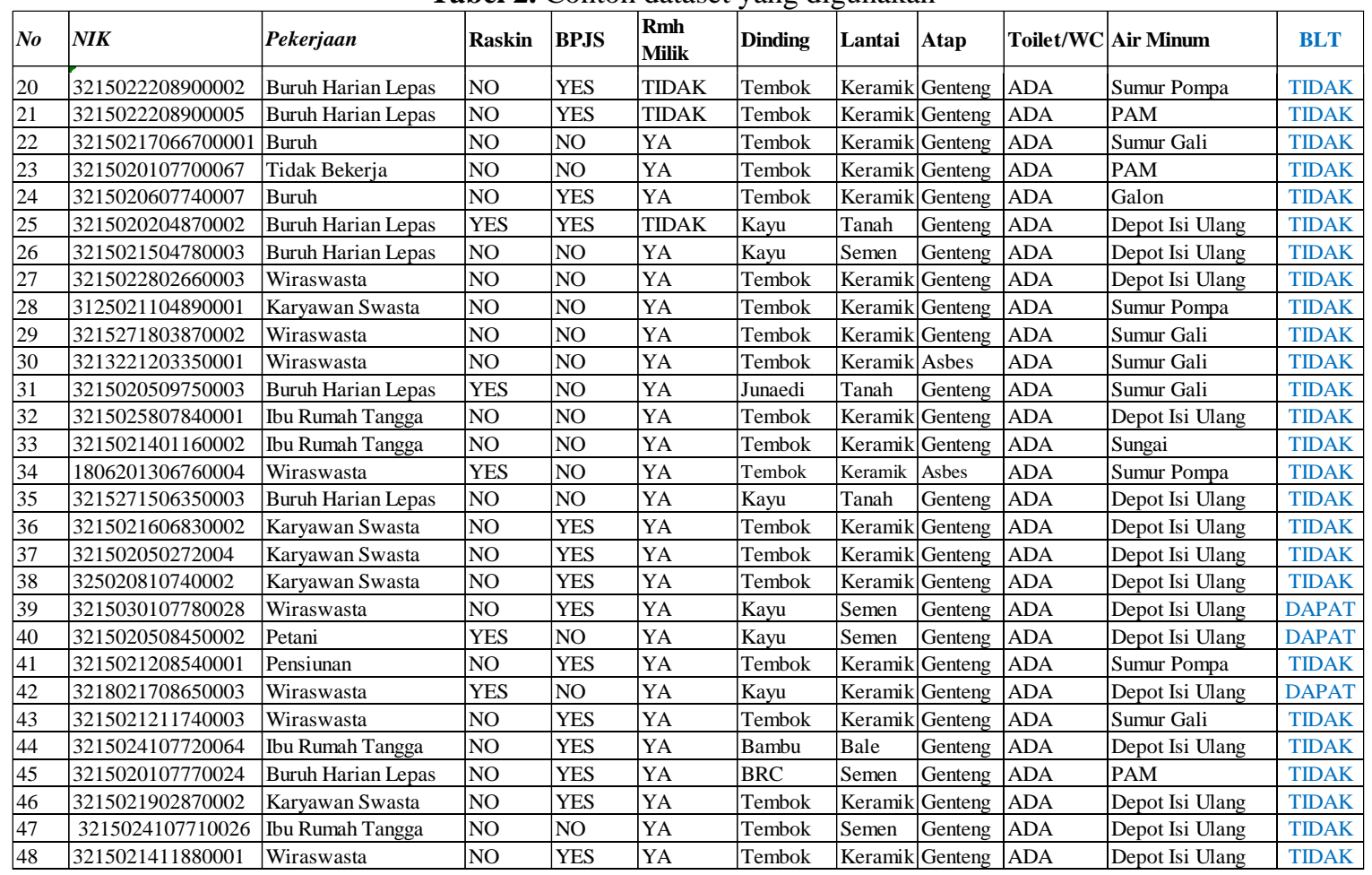


PETIR: Jurnal Pengkajian dan Penerapan Teknik Informatika Vol. 13, No. 1, Maret 2020, P-ISSN 1978-9262, E-ISSN 2655-5018

DOI: https://doi.org/10.33322/petir.v13i1.768

Persyaratan Keluarga Dapat BLT menurut Dasar hukum pelaksanaan program adalah Instruksi Presiden Republik Indonesia Nomor 3 Tahun 2008 tanggal 14 Mei 2008 Tentang Pelaksanaan Program Bantuan Langsung Tunai Untuk Rumah Tangga Sasaran (RTS). Presiden Republik Indonesia, Untuk kelancaran pelaksanaan program pemberian bantuan langsung tunai kepada rumah tangga miskin dalam rangka kompensasi pengurangan subsidi Bahan Bakar Minyak (BBM), dengan ini menginstruksikan: Kepada:
Luas lantai Rumah
$=<8 \mathrm{~m}^{2}$
Jenis lantai rumah
= Tanah, Bamboo, Kayu murahan
Dinding
Fasiltas WC
= Bamboo, Rumbia, Bahan kwalitas rendah
Sumber Air Minum
$=$ Tidak memiliki
$=$ Sumur, Air tidak terlindung
Penerangan
$=$ Bukan listrik
Makan
$=2 \mathrm{x}$ sehari
Pakaian
$=1$ kali dalam setahun
Lahan Petani
$=<1 / 2$ hektar, Buruh tani, Nelayan, Buruh bangunan
Pendapatan
$=<600 \mathrm{ribu}$

Tabel 3. Perbandingan Hasil prediction dengan judgement

\begin{tabular}{|c|c|c|c|c|c|c|c|c|c|c|}
\hline Air Minum & BPJS & Dinding & Lantai & Pekerjaan & $\begin{array}{c}\text { Rmh } \\
\text { Milik } \\
\text { Sendiri }\end{array}$ & \begin{tabular}{l|} 
Toilet \\
/WC
\end{tabular} & BLT & $\begin{array}{c}\text { prediction } \\
\text { (BLT) }\end{array}$ & $\begin{array}{c}\text { confidence } \\
\text { (DAPAT) }\end{array}$ & $\begin{array}{c}\text { confidence } \\
\text { (TIDAK) }\end{array}$ \\
\hline Depot Isi Ulang & YES & Tembok & Semen & Ibu Rumah Tangga & YA & ADA & TIDAK & TIDAK & 0.1 & 0.9 \\
\hline Depot Isi Ulang & YES & Tembok & Semen & Wiraswasta & YA & ADA & TIDAK & TIDAK & 0.1 & 0.9 \\
\hline Depot Isi Ulang & NO & Tembok & Semen & Buruh Harian Lepas & YA & ADA & TIDAK & TIDAK & 0.0 & 1.0 \\
\hline Depot Isi Ulang & NO & Tembok & Semen & Buruh & YA & ADA & TIDAK & TIDAK & 0.0 & 1.0 \\
\hline Sumur Pompa & YES & Tembok & Semen & Pensiunan & YA & ADA & TIDAK & TIDAK & 0.0 & 1.0 \\
\hline Depot Isi Ulang & NO & Tembok & Semen & Wiraswasta & YA & ADA & TIDAK & TIDAK & 0.0 & 1.0 \\
\hline Depot Isi Ulang & YES & Tembok & Keramik & Karyawan Swasta & YA & ADA & TIDAK & TIDAK & 0.0 & 1.0 \\
\hline PAM & NO & Tembok & Keramik & Ibu Rumah Tangga & YA & ADA & TIDAK & TIDAK & 0.0 & 1.0 \\
\hline PAM & YES & Tembok & Keramik & Karyawan & YA & ADA & TIDAK & TIDAK & 0.0 & 1.0 \\
\hline PAM & YES & Tembok & Keramik & Buruh Harian Lepas & TIDAK & ADA & TIDAK & TIDAK & 0.0 & 1.0 \\
\hline Sumur Gali & NO & Tembok & Keramik & Buruh & YA & ADA & TIDAK & TIDAK & 0.0 & 1.0 \\
\hline Depot Isi Ulang & YES & Kayu & Tanah & Buruh Harian Lepas & TIDAK & ADA & TIDAK & TIDAK & 0.2 & 0.8 \\
\hline Sumur Pompa & NO & Tembok & Keramik & Karyawan Swasta & YA & ADA & TIDAK & TIDAK & 0.0 & 1.0 \\
\hline Sumur Gali & NO & Tembok & Keramik & Wiraswasta & YA & ADA & TIDAK & TIDAK & 0.0 & 1.0 \\
\hline Sumur Gali & NO & Tembok & Keramik & Wiraswasta & YA & ADA & TIDAK & TIDAK & 0.0 & 1.0 \\
\hline Depot Isi Ulang & NO & Tembok & Keramik & Ibu Rumah Tangga & YA & ADA & TIDAK & TIDAK & 0.0 & 1.0 \\
\hline Sungai & NO & Tembok & Keramik & Ibu Rumah Tangga & YA & ADA & TIDAK & TIDAK & 0.0 & 1.0 \\
\hline Sumur Pompa & NO & Tembok & Keramik & Wiraswasta & YA & ADA & TIDAK & TIDAK & 0.0 & 1.0 \\
\hline PAM & YES & BRC & Semen & Buruh Harian Lepas & YA & ADA & TIDAK & TIDAK & 0.3 & 0.7 \\
\hline Depot Isi Ulang & YES & Tembok & Keramik & Wiraswasta & YA & ADA & TIDAK & TIDAK & 0.1 & 0.9 \\
\hline Depot Isi Ulang & NO & Tembok & Keramik & Buruh Harian Lepas & YA & ADA & TIDAK & TIDAK & 0.0 & 1.0 \\
\hline Sumur Gali & YES & Dinding & Keramik & Buruh Harian Lepas & YA & ADA & TIDAK & TIDAK & 0.1 & 0.9 \\
\hline Sumur Gali & NO & BRC & Semen & Ibu Rumah Tangga & TIDAK & ADA & TIDAK & DAPAT & 0.6 & 0.4 \\
\hline Depot Isi Ulang & NO & Tembok & Keramik & Buruh Harian Lepas & TIDAK & TIDAK & TIDAK & TIDAK & 0.0 & 1.0 \\
\hline Depot Isi Ulang & NO & Tembok & Keramik & Ibu Rumah Tangga & YA & TIDAK & TIDAK & TIDAK & 0.0 & 1.0 \\
\hline Sumur Gali & NO & BRC & Semen & Buruh Harian Lepas & YA & ADA & DAPAT & TIDAK & 0.3 & 0.7 \\
\hline Sumur Pompa & YES & Tembok & Keramik & Wiraswasta & TIDAK & ADA & TIDAK & TIDAK & 0.1 & 0.9 \\
\hline Sungai & YES & BRC & Semen & Pemandu Golf & TIDAK & ADA & TIDAK & TIDAK & 0.4 & 0.6 \\
\hline PAM & NO & BRC & Semen & Wiraswasta & YA & TIDAK & TIDAK & TIDAK & 0.2 & 0.8 \\
\hline Depot Isi Ulang & NO & Tembok & Keramik & Wiraswasta & YA & ADA & TIDAK & TIDAK & 0.0 & 1.0 \\
\hline Depot isi ulang & NO & Tembok & Keramik & Buruh Harian Lepas & YA & ADA & TIDAK & TIDAK & 0.0 & 1.0 \\
\hline Depot Isi Ulang & YES & Tembok & Semen & Buruh Harian Lepas & YA & TIDAK & TIDAK & TIDAK & 0.1 & 0.9 \\
\hline Depot Isi Ulang & NO & Tembok & Semen & Buruh Harian Lepas & YA & TIDAK & TIDAK & TIDAK & 0.1 & 0.9 \\
\hline Sumur Gali & NO & Tembok & Keramik & Wiraswasta & YA & ADA & TIDAK & TIDAK & 0.0 & 1.0 \\
\hline Sumur Pompo & NO & Kayu & Semen & Buruh Harian Lepas & YA & ADA & TIDAK & TIDAK & 0.2 & 0.8 \\
\hline Sumur Pompo & NO & Tembok & Keramik & Petani & YA & ADA & TIDAK & TIDAK & 0.0 & 1.0 \\
\hline
\end{tabular}


PETIR: Jurnal Pengkajian dan Penerapan Teknik Informatika Vol. 13, No. 1, Maret 2020, P-ISSN 1978-9262, E-ISSN 2655-5018 DOI: https://doi.org/10.33322/petir.v13i1.768

\begin{tabular}{|c|c|c|c|c|c|c|c|c|c|c|}
\hline Pipa & NO & Kayu & Keramik & Buruh Harian Lepas & YA & ADA & DAPAT & TIDAK & 0.0 & 1.0 \\
\hline Pipa & NO & Kayu & Keramik & Buruh & TIDAK & TIDAK & TIDAK & TIDAK & 0.1 & 0.9 \\
\hline Sumur Pompa & NO & Tembok & Semen & Wiraswasta & YA & ADA & TIDAK & TIDAK & 0.0 & 1.0 \\
\hline Depot Isi Ulang & NO & Tembok & Keramik & Buruh Harian Lepas & YA & TIDAK & TIDAK & TIDAK & 0.0 & 1.0 \\
\hline Depot Isi Ulang & NO & Tembok & Tanah & Buruh Harian Lepas & YA & ADA & TIDAK & TIDAK & 0.0 & 1.0 \\
\hline PAM & NO & Tembok & kramik & Buruh Tani & TIDAK & TIDAK & TIDAK & TIDAK & 0.0 & 1.0 \\
\hline Depot isi ulang & NO & Tembok & Keramik & Karyawan Swasta & YA & TIDAK & TIDAK & TIDAK & 0.0 & 1.0 \\
\hline Depot Isi ulang & YES & Bambu & Kayu & Buruh Harian Lepas & TIDAK & ADA & TIDAK & TIDAK & 0.0 & 1.0 \\
\hline Depot Isi Ulang & YES & Tembok & Keramik & Wiraswasta & YA & ADA & TIDAK & TIDAK & 0.1 & 0.9 \\
\hline Depot Isi Ulang & NO & Tembok & Keramik & Karyawan Swasta & TIDAK & TIDAK & TIDAK & TIDAK & 0.0 & 1.0 \\
\hline Depot Isi Ulang & NO & Tembok & Keramik & Buruh Harian Lepas & TIDAK & TIDAK & TIDAK & TIDAK & 0.0 & 1.0 \\
\hline Depot Isi Ulang & NO & Tembok & Tanah & Buruh Harian Lepas & TIDAK & ADA & TIDAK & TIDAK & 0.1 & 0.9 \\
\hline Depot isi ulang & NO & Bambu & Keramik & Buruh Harian Lepas & YA & TIDAK & DAPAT & TIDAK & 0.0 & 1.0 \\
\hline PAM & YES & Tembok & Keramik & Buruh Harian Lepas & YA & TIDAK & TIDAK & TIDAK & 0.0 & 1.0 \\
\hline Depot isi ulang & NO & Tembok & Keramik & Wiraswasta & TIDAK & TIDAK & TIDAK & TIDAK & 0.0 & 1.0 \\
\hline Depot isi ulang & NO & Tembok & Keramik & WIRASWASTA & TIDAK & TIDAK & TIDAK & TIDAK & 0.0 & 1.0 \\
\hline PAM & NO & Tembok & Semen & Petani & YA & ADA & TIDAK & TIDAK & 0.0 & 1.0 \\
\hline Depot Isi Ulang & YES & Tembok & Semen & Karyawan Swasta & YA & ADA & TIDAK & TIDAK & 0.0 & 1.0 \\
\hline Depot Isi Ulang & YES & Tembok & Semen & TNI & YA & ADA & TIDAK & TIDAK & 0.1 & 0.9 \\
\hline Depot Isi Ulang & YES & Tembok & Semen & Buruh Harian Lepas & YA & ADA & TIDAK & TIDAK & 0.0 & 1.0 \\
\hline Depot Isi Ulang & YES & Tembok & Semen & Karyawan Swasta & TIDAK & ADA & TIDAK & TIDAK & 0.0 & 1.0 \\
\hline Sumur Gali & YES & Tembok & Semen & Wiraswasta & TIDAK & ADA & TIDAK & TIDAK & 0.1 & 0.9 \\
\hline Depot Isi Ulang & YES & Tembok & Semen & Buruh Harian Lepas & YA & ADA & TIDAK & TIDAK & 0.0 & 1.0 \\
\hline Depot Isi Ulang & YES & Tembok & Semen & Wiraswasta & YA & ADA & TIDAK & TIDAK & 0.1 & 0.9 \\
\hline PAM & YES & Tembok & Semen & Buruh Harian Lepas & YA & ADA & TIDAK & TIDAK & 0.0 & 1.0 \\
\hline Sumur Pompa & NO & Tembok & Semen & Petani & YA & ADA & TIDAK & TIDAK & 0.0 & 1.0 \\
\hline PAM & YES & Tembok & Semen & Buruh Harian Lepas & TIDAK & ADA & TIDAK & TIDAK & 0.0 & 1.0 \\
\hline PAM & NO & Tembok & Semen & Wiraswasta & YA & ADA & TIDAK & TIDAK & 0.0 & 1.0 \\
\hline Depot Isi Ulang & NO & Tembok & Semen & Buruh & YA & ADA & TIDAK & TIDAK & 0.0 & 1.0 \\
\hline Depot isi ulang & NO & Tembok & Tanah & Buruh & TIDAK & TIDAK & TIDAK & TIDAK & 0.0 & 1.0 \\
\hline PAM & NO & Tembok & Tanah & Ibu Rumah Tangga & YA & ADA & TIDAK & TIDAK & 0.0 & 1.0 \\
\hline Sumur Gali & NO & Tembok & Tanah & Petani & TIDAK & ADA & TIDAK & TIDAK & 0.2 & 0.8 \\
\hline PAM & NO & Tembok & Bambu & Petani & YA & TIDAK & DAPAT & TIDAK & 0.1 & 0.9 \\
\hline Sumur Gali & YES & Tembok & Keramik & Pegawai Negeri Sipil & YA & ADA & TIDAK & TIDAK & 0.1 & 0.9 \\
\hline PAM & NO & Tembok & v & Buruh Harian Lepas & YA & ADA & TIDAK & TIDAK & 0.0 & 1.0 \\
\hline Isi ulang \& Sumur & NO & GRC & Kayu & Petani & YA & ADA & TIDAK & TIDAK & 0.1 & 0.9 \\
\hline Depot isi ulang & NO & GRC & Semen & Karyawan Swasta & YA & ADA & TIDAK & TIDAK & 0.1 & 0.9 \\
\hline PAM & YES & Tembok 8 & Keramik & Pedagang & YA & ADA & TIDAK & TIDAK & 0.0 & 1.0 \\
\hline PAM & NO & Tembok & Keramik & Karyawan Swasta & YA & ADA & DAPAT & TIDAK & 0.0 & 1.0 \\
\hline Depot isi ulang & NO & Tembok & Keramik & Wiraswasta & TIDAK & TIDAK & TIDAK & TIDAK & 0.0 & 1.0 \\
\hline PAM & NO & Tembok & Keramik & Wiraswasta & YA & TIDAK & TIDAK & TIDAK & 0.0 & 1.0 \\
\hline Sumur Gali & NO & Tembok & Keramik & Karyawan & YA & TIDAK & TIDAK & TIDAK & 0.0 & 1.0 \\
\hline Sumur Gali & NO & Tembok & Keramik & Buruh & YA & TIDAK & TIDAK & TIDAK & 0.0 & 1.0 \\
\hline PAM & NO & Tembok & Keramik & Wiraswasta & YA & TIDAK & TIDAK & TIDAK & 0.0 & 1.0 \\
\hline Sumur Gali & NO & Tembok & Keramik & Karyawan & YA & TIDAK & TIDAK & TIDAK & 0.0 & 1.0 \\
\hline Sumur Gali & NO & Tembok & Keramik & Buruh & YA & TIDAK & TIDAK & TIDAK & 0.0 & 1.0 \\
\hline PAM & NO & Tembok & Keramik & Buruh & TIDAK & TIDAK & TIDAK & TIDAK & 0.0 & 1.0 \\
\hline PAM & NO & Tembok & Keramik & Buruh & TIDAK & TIDAK & TIDAK & TIDAK & 0.0 & 1.0 \\
\hline PAM & YES & Tembok & Keramik & Karyawan & YA & TIDAK & TIDAK & TIDAK & 0.0 & 1.0 \\
\hline PAM & NO & Tembok & Keramik & Buruh & TIDAK & TIDAK & TIDAK & TIDAK & 0.0 & 1.0 \\
\hline PAM & YES & Tembok & Keramik & Karyawan & YA & TIDAK & TIDAK & TIDAK & 0.0 & 1.0 \\
\hline PAM & NO & Tembok & Keramik & TNI & YA & TIDAK & TIDAK & TIDAK & 0.0 & 1.0 \\
\hline PAM & YES & Tembok & Keramik & Supir & YA & TIDAK & TIDAK & TIDAK & 0.0 & 1.0 \\
\hline PAM/Depot Isi U & NO & Tembok & Keramik & Karyawan & YA & TIDAK & TIDAK & TIDAK & 0.0 & 1.0 \\
\hline PAM & NO & Tembok & Keramik & Wiraswasta & YA & TIDAK & TIDAK & TIDAK & 0.0 & 1.0 \\
\hline PAM & NO & Tembok & Keramik & PNS & YA & TIDAK & TIDAK & TIDAK & 0.0 & 1.0 \\
\hline PAM & NO & Tembok & Keramik & Ibu Rumah Tangga & YA & TIDAK & TIDAK & TIDAK & 0.0 & 1.0 \\
\hline PAM & NO & Tembok & Keramik & Karyawan & YA & TIDAK & TIDAK & TIDAK & 0.0 & 1.0 \\
\hline PAM & NO & Tembok & Keramik & Supir & TIDAK & TIDAK & TIDAK & TIDAK & 0.0 & 1.0 \\
\hline PAM & NO & Tembok & Keramik & Tani & YA & TIDAK & TIDAK & TIDAK & 0.0 & 1.0 \\
\hline
\end{tabular}


PETIR: Jurnal Pengkajian dan Penerapan Teknik Informatika Vol. 13, No. 1, Maret 2020, P-ISSN 1978-9262, E-ISSN 2655-5018 DOI: https://doi.org/10.33322/petir.v13i1.768

\begin{tabular}{|c|c|c|c|c|c|c|c|c|c|c|}
\hline Sumur Gali & NO & Tembok & Keramik & Buruh Harian Lepas & TIDAK & TIDAK & TIDAK & TIDAK & 0.0 & 1.0 \\
\hline Sumur Pompa & NO & Tembok & Keramik & Wiraswasta & YA & TIDAK & TIDAK & TIDAK & 0.0 & 1.0 \\
\hline Mata air & NO & Tembok & Keramik & Wiraswasta & YA & TIDAK & TIDAK & TIDAK & 0.0 & 1.0 \\
\hline Depot Isi Ulang & NO & Tembok & Keramik & Supir & YA & TIDAK & TIDAK & TIDAK & 0.0 & 1.0 \\
\hline Depot Isi Ulang & NO & Kayu & Keramik & Buruh & TIDAK & TIDAK & TIDAK & TIDAK & 0.0 & 1.0 \\
\hline PAM & NO & Tembok & Keramik & Wiraswasta & YA & ADA & TIDAK & TIDAK & 0.0 & 1.0 \\
\hline PAM & YES & Tembok & Keramik & Supir & YA & ADA & TIDAK & TIDAK & 0.0 & 1.0 \\
\hline PAM & NO & Tembok & Keramik & Buruh & YA & ADA & TIDAK & TIDAK & 0.0 & 1.0 \\
\hline PAM & YES & Tembok & Keramik & Petani & YA & ADA & TIDAK & TIDAK & 0.1 & 0.9 \\
\hline Sumur & NO & Kayu & Tanah & Buruh & YA & TIDAK & TIDAK & TIDAK & 0.0 & 1.0 \\
\hline Sumur & YES & Kayu & Tanah & Ibu Rumah Tangga & YA & ADA & TIDAK & TIDAK & 0.1 & 0.9 \\
\hline Sumur Gali & NO & Tembok & Keramik & Buruh & YA & TIDAK & TIDAK & TIDAK & 0.0 & 1.0 \\
\hline PAM & NO & Tembok & Keramik & Tukang Bangunan & TIDAK & TIDAK & TIDAK & TIDAK & 0.0 & 1.0 \\
\hline Mata Air dan PAN & NO & Tembok & Keramik & Tani & YA & TIDAK & TIDAK & TIDAK & 0.0 & 1.0 \\
\hline PAM & NO & Tembok & Keramik & Kepala Keluarga & YA & ADA & TIDAK & TIDAK & 0.0 & 1.0 \\
\hline
\end{tabular}

Hasil penilitian ini dapat dibandingkan antara hasil dari performance algoritma jaringan syaraf tiruan (Deep Learning) dengan hasil aktual dilapangan. Jadi banyak yang tidak sesuaian, algoritma neural network kurang baik performance untuk Analisa yang berbentuk teks karena Algoritma Neural network lebih bagus ketika datasetnya berbentuk angka (numerik). untuk lebih jelas bisa dilihat tabel 3 diatas. Berikut hasil penelitian dengan berbagai bentuk.

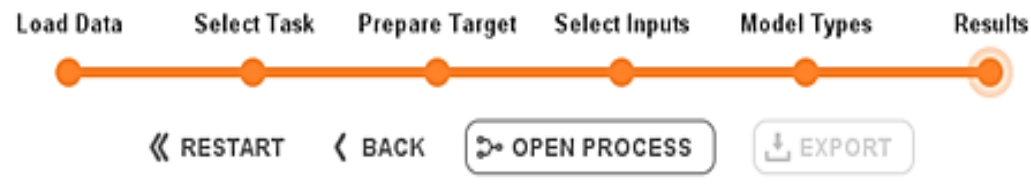

\section{Deep Learning - Model}

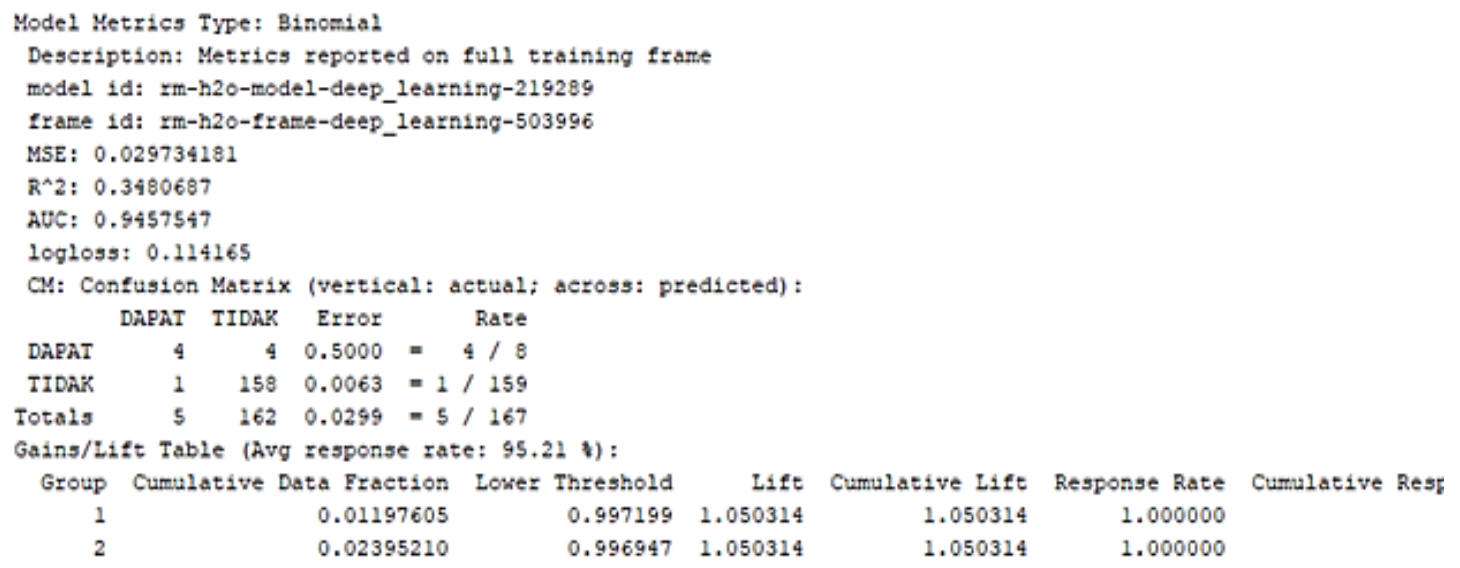

Gambar 2. Model pembelajaran Deep Learning / Jaringan Syaraf Tiruan 
PETIR: Jurnal Pengkajian dan Penerapan Teknik Informatika Vol. 13, No. 1, Maret 2020, P-ISSN 1978-9262, E-ISSN 2655-5018 DOI: https://doi.org/10.33322/petir.v13i1.768

\section{Important Factors for TIDAK}

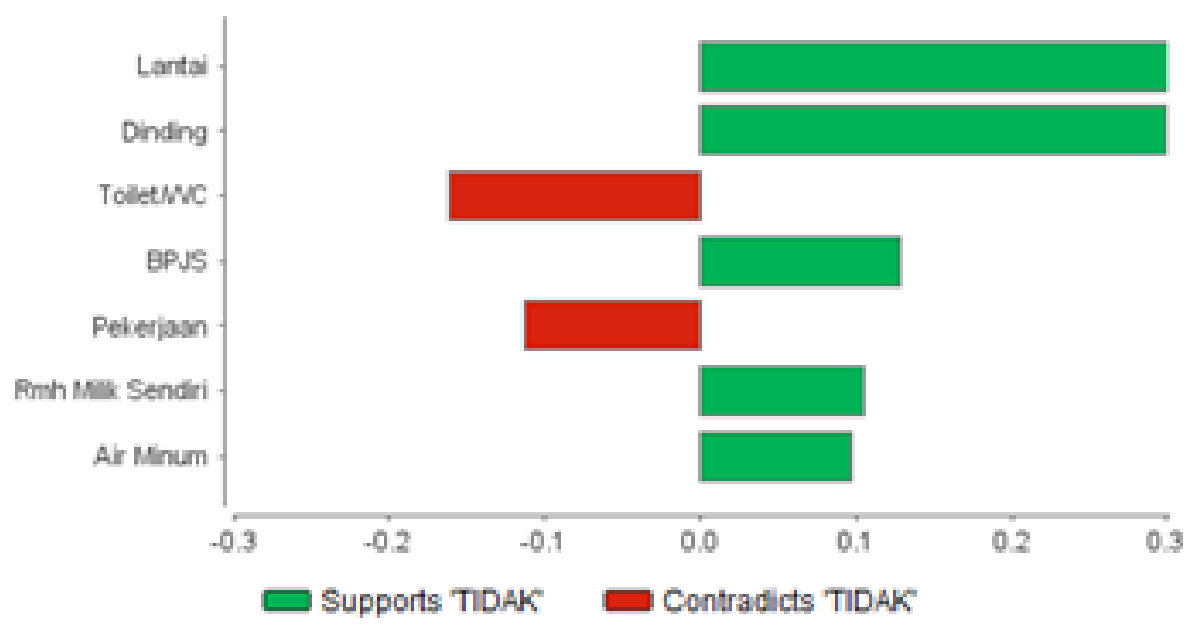

Gambar 3. Hasil Important Factor

Important factors adalah gambar ilustrasi support tidak dan contradicts tidak untuk melihat kondisi data yang digunakan bahwa, bahwa kategori data sebenarnya dilapangan tidak bagus. Misalnya harusnya data dapat bantuan pemerintah tapi kenyataan tidak dapat.

\begin{tabular}{|l|l|l|l|}
\hline \multicolumn{2}{|l|}{ accuracy: $\mathbf{9 4 . 9 2 \% + 1 . 5 . 2 6 \%}$ (micro average: $\mathbf{9 4 . 9 4 \% )}$} & \\
\hline & true DAPAT & true TIDAK & $0.00 \%$ \\
\hline pred. DAPAT & 0 & 0 & $94.94 \%$ \\
\hline pred. TIDAK & 4 & 75 & \\
\hline class recall & $0.00 \%$ & $100.00 \%$ & \\
\hline
\end{tabular}

Gambar 4. Tampilan hasil conflusion matrix

Gambar 3 menampilkan hasil performance algoritma jaringan syaraf tiruan (deep learning) pada penelitian ini. Dalam penelitian juga hasil dapat ditampilkan berupa confusion matrix sebagai tolak ukur keberhasilan, yang terdiri dari accuracy, recall dan precision.

\section{KESIMPULAN DAN SARAN}

\subsection{Kesimpulan}

Setelah melakukan penelitian ini ada beberapa hasil yang didapat. Berikut hasil penelitian adalah:

1. Tingkat Accuracy yang didapatkan adalah $94.96 \%$

2. Penelitian dengan algoritma Neural network (Deep learning) bisa membantu untuk mengklasifikasi dengan baik.

3. Penyaluran BLT yang dilakukan di Desa Tamanmekar masih terdapat penyaluran yang tidak tepat sasaran, jika dibanding dengan aturan dari pemerintah. 
PETIR: Jurnal Pengkajian dan Penerapan Teknik Informatika Vol. 13, No. 1, Maret 2020, P-ISSN 1978-9262, E-ISSN 2655-5018

\subsection{Saran}

Penelitian telah dilakukan, peneliti memberikan beberapa saran:

1. Mengingat hasil performance algoritma tersebut belum maksimal perlu dilakukan dengan algoritma yang lain.

2. Penelitian berikutnya bisa menggunakan tools yang ada, atau dengan tools yang lain.

\section{UCAPAN TERIMAKASIH}

Ucapan terima kasih Kementrian Riset dan teknologi yang memberian pembiayaan penelitian ini tahun anggaran 2019.

\section{DAFTAR PUSTAKA}

[1] Syamsi, Ibnu. 2000. Pengambilan keputusan dan Sistem Informasi. (Jakarta : Bumi Aksara), hlm 5 .

[2] Mintzberg Herry, Guided tour trough the wilds of strategic management, New york Free Press,1998.

[3] Yunanto et al 2017 , "Pemetaan Kecelakaan Lalu Lintas Berbasis Klasifikasi Naïve Bayes dengan Parameter Infrastruktur Jalan".

[4] Hidayatullah A F, et al, 2018, "Analisis Kualitas Data dan Klasifikasi Data Pasien Kanker"

[5] Gorunescu, F. 2011. Data Mining Concept Model and Techniques. Berlin: Springer. ISBN 978-3-642-19720-8.

[6] Larose D, T., 2005, Discovering knowledge in data : an introduction to data mining, Jhon Wiley \& Sons Inc.

[7] Han \& Kamber. 2006. Data Mining: Concepts and Techniques, 2nd ed.

[8] Newman, William H. 1963. Admnistrative Action. The tecnique of organization and management (second edition). Prentice Hall Inc.

[9] Maimon, et all. Data mining and knowledge discovery handbook. Vol. 2. New York:Springer, 2005. 